\title{
Sistem Pendukung Keputusan Klinis dengan Memanfaatkan Jaringan Syaraf Tiruan Untuk Mendeteksi Stadium Penderita Kanker Paru-Paru Jenis Karsinoma Bukan Sel Kecil
}

\author{
R. Kurniawan dan S. Hartati
}

\begin{abstract}
Lung cancer is leading cause of death in the cancer group. In general, lung cancer has some symptoms, but at an early stage, symptoms are not perceived by the patient. As a result, when patients go to hospital, lung cancer has been diagnosed in middle or high stage. For early detection of lung cancer, necessary a decision support system based on computerized technology that can be utilized by doctor needed to detection lung cancer. The clinical decision support system will help to determine specific medical treatment. The clinical decision support system capable to know data input and produce output result by learning process. The learning process is part of process in artificial neural network (ANN). Many methods used in ANN as Backpropagation (BP)learning algorithm. BP used to produce output result in decision support system.
\end{abstract}

Keywords-- lung cancer, stage, clinical decision support systems, neural network, multilayer perceptron, backpropagation algorithm

\section{Pendahuluan}

$\mathbf{K}^{\mathrm{a}}$ anker paru-paru merupakan salah satu penyebab kematian dalam kelompok kanker. Secara umum, kanker paru memiliki sejumlah gejala, antara lain: batuk terus-menerus, nyeri dada, batuk darah, napas tersengal-sengal, serak, berat badan menurun, dan selalu merasa letih. Pada stadium awal, gejala-gejala ini sering tidak dirasakan oleh penderita, akibatnya ketika penderita pergi ke rumah sakit dan kemudian penyakit terdiagnosis, penyakit kanker paru itu sudah berada dalam stadium menengah atau akhir.

Agar dapat mendeteksi dini penyakit mematikan ini, perlu dikembangkan teknologi yang dapat dimanfaatkan pihak medis secara cepat dan tepat agar penanggulangan dan pengobatan penyakit ini bisa dilakukan.

Rio Kurniawan, Mahasiswa S2 Ilmu Komputer, FMIPA, UGM, Yogyakarta, e-mail: riokurniawan@mail.ugm.ac.id,

Sri Hartati, Staf Pengajar Jurusan Ilmu Komputer dan Elektronika, FMIPA, Universitas Gadjah Mada, Yogyakarta, e-mail:shartati@ugm.ac.id
Salah satu teknologi yang dapat diberdayakan untuk medis adalah sistem pendukung keputusan klinis (Clinical Decision Support Systems).

Pada umumnya sistem pendukung keputusan klinis dikembangkan dengan mengintegrasikan pengetahuan medik, data pasien, dan mesin learning agar di peroleh saran medis yang spesifik. Sistem pendukung keputusan klinis dapat mengenali input data dan memberikan output secara benar karena sistem melakukan pembelajaran, pembelajaran ini merupakan bagian dari metode jaringan syaraf tiruan (JST) yang telah banyak di implementasikan pada banyak bidang pengetahuan.

Besarnya harapan agar penyakit kanker paruparu dapat dideteksi secara dini maka perlu dirancang dan dibangun sebuah sistem pendukung keputusan klinis yang dapat membantu penanganan dan pendeteksian kanker paru.

Berdasarkan uraian pada latar belakang di atas, maka dapat dirumuskan suatu permasalahan yaitu: bagaimana membangun sebuah sistem pendukung keputusan klinis untuk mendeteksi stadium penderita kanker paru-paru.

\section{METOde PENELITIAN}

Sistem pendukung keputusan klinis (Clinical Decision Support Systems) merupakan sistem yang dibangun untuk keperluan pendukung pengambilan keputusan klinis dengan memanfaatkan pengetahuan dengan menggunakan dua atau lebih data pasien untuk memberikan saran pada kasus tertentu. Pada umumnya sistem pendukung keputusan klinis ini dikembangkan dengan mengintegrasikan pengetahuan medik, data pasien, dan mesin learning untuk di dapatkan saran medis yang spesifik.

Clinical Decision Support Systems adalah program komputer yang dirancang untuk menyediakan dukungan para ahli dalam membuat keputusan klinis. Tujuan sistem ini adalah membantu para profesional di bidang kesehatan dalam menganalisis data pasien, membuat keputusan berdasarkan diagnosis, melakukan 
pencegahan, dan treatment terhadap permasalahan kesehatan [1].

\subsection{Jaringan Syaraf Tiruan (JST)}

Jaringan syaraf tiruan merupakan sistem pemproses informasi yang memiliki karakteristik mirip dengan jaringan syaraf biologi, jaringan syaraf tiruan merupakan sistem komputasi yang didasarkan atas pemodelan sistem syaraf biologis (neurons) melalui pendekatan dari sifat-sifat komputasi biologis (biological computation), jaringan syaraf tiruan membuat model sistem komputasi yang dapat menirukan cara kerja jaringan syaraf biologi [2].

Jaringan syaraf tiruan dibentuk sebagai generalisasi model matematika dari jaringan syaraf biologi dengan asumsi sebagai berikut:

1. Pemrosesan informasi terjadi pada banyak elemen sederhana (neurons).

2. Sinyal dikirimkan diantara neuron-neuron melalui penghubung penghubung.

3. Penghubung antar neuron memiliki bobot yang akan memperkuat atau memperlemah sinyal.

4. Untuk menentukan keluaran, setiap neuron menggunakan fungsi aktivasi yang dikenakan pada penjumlahan masukan yang diterima. Besarnya keluaran ini selanjutnya dibandingkan dengan suatu batas ambang tertentu.

Perubahan harga bobot koneksi dapat dilakukan dengan berbagai cara, tergantung pada jenis algoritma pelatihan yang digunakan. Dengan mengatur besarnya nilai bobot ini diharapkan kinerja jaringan dalam mengenali pola akan meningkat.

\subsection{Multilayer Perceptron}

Multilayer Perceptron Neural Network merupakan sejenis jaringan syaraf tiruan yang memiliki kemampuan untuk mendeteksi atau melakukan analisa untuk permasalahan yang bersifat komplek, seperti pada masalah pemrosesan bahasa, pengenalan suatu pola serta pemrosesan data image. Secara umum, jaringan terdiri dari sejumlah unit neuron sebagai lapisan input, satu atau lebih lapisan tersembunyi, dan sebuah lapisan output. Arsitektur Multilayer Perceptron Neural network ditunjukkan pada Gambar 1 dimana x merupakan input, y adalah output, w merupakan bobot, semua elemen terhubung pada simpul $\sigma$.

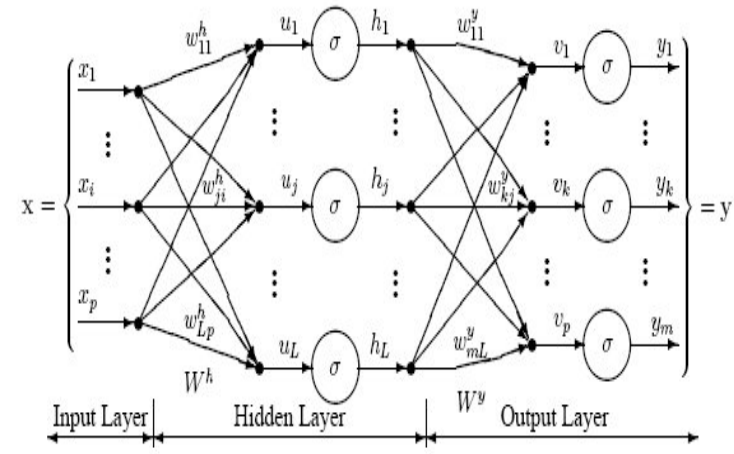

Gambar 1 Arsitektur Multilayer Perceptron

Backpropagation merupakan algoritma MLP yang menggunakan prinsip supervised learning. Propagasi balik (ke arah lapisan input) terjadi setelah jaringan menghasilkan output yang mengandung error. Pada fase ini seluruh bobot synaptic yang tidak memiliki aktivasi nol dalam jaringan akan disesuaikan untuk memperkecil error yang terjadi (error correction rule). Untuk pelatihan jaringan, pasangan fase propagasi ke depan dan balik dilakukan secara berulang untuk satu set data latihan, kemudian diulangi untuk sejumlah epoch (satu sesi lewatan untuk seluruh data latihan dalam sebuah proses pelatihan jaringan) sampai error yang terjadi mencapai batas kecil toleransi tertentu atau nol.

Sistem pembelajaran merupakan proses penambahan pengetahuan pada JST yang sifatnya kontinuitas sehingga pada saat digunakan, pengetahuan tersebut akan dieksploitasikan secara maksimal dalam mengenali objek.

\subsection{Algoritma Backpropagation}

Metode backpropagation ini merupakan metode pembelajaran lanjut yang dikembangkan dari aturan perceptron [3]. Algoritma pelatihan backpropagation pada dasarnya terdiri dari tahapan-tahapan, yaitu:

1. Inisialisasi bobot (ditentukan oleh bilangan acak yang kecil, antara 0 sampai 1)

2. Selama kondisi berhenti tidak terpenuhi, lakukan langkah 4 sampai 10

3. untuk setiap pasangan vektor pelatihan, lakukan langkah 4 sampai langkah 8 .

Feedforwad

4. Setiap neuron pada lapisan masukan ( $\mathrm{Xi}$, $\mathrm{i}=1,2, \ldots, \mathrm{n})$ menerima sinyal masukan xi dan menjalankan sinyal tersebut ke semua neuron pada lapisan selanjutnya (dalam hal ini adalah lapisan tersembunyi) 
5. untuk setiap neuron dalam lapisan tersembunyi $\quad(Z j, \quad j=1, \quad 2, \quad \ldots, p)$, jumlahkan bobotnya dengan sinyal masukannya masing-masing:

$Z_{i n_{j}}=v_{o j}+\sum_{i=1}^{n} x_{i} v_{j}$

Terapkan fungsi aktivasi untuk untuk menghitung nilai sinyal keluaran

$Z_{j}=f\left(Z_{i n_{j}}\right)$

Kemudian kirimkan sinyal ini ke semua neuron pada lapisan berikutnya (dalam hal ini adalah lapisan keluaran)

6. Untuk setiap neuron pada lapisan keluaran ( $\mathrm{Yk}, \mathrm{k}=1,2, \ldots, \mathrm{m})$, jumlahkan bobotnya dengan sinyal masukannya masing-masing

$Y_{i n_{k}}=w_{0 j}+\sum_{i=1}^{p} z_{j} w_{k}$

Terapkan fungsi aktivasi untuk menghitung nilai sinyal keluaran

$Y_{k}=f\left(y_{i n_{k}}\right)$

Back propagation of error

7. Setiap neuron pada lapisan keluaran ( $\mathrm{Yk}$, $\mathrm{k}=1,2, \ldots, \mathrm{m})$ menerima sebuah pola target yang berhubungan dengan pola masukan pelatihan kemudian hitung kesalahannya

$\delta_{k}=\left(t_{k}-y_{k}\right) f^{\prime}\left(y_{i n_{k}}\right)$

Hitung perubahan bobotnya (digunakan nanti untuk mengubah nilai $w_{j k}$ )

$\Delta w_{j k}=\alpha \cdot \delta_{k} \cdot z_{k}$

Hitung perubahan perubahan biasnya (digunakan nanti untuk mengubah nilai $\left.w_{0 k}\right)$

$\Delta w_{0 k}=\alpha \cdot \delta_{k}$

8. Untuk setiap neuron pada lapisan tersembunyi ( $\mathrm{Zj}, \mathrm{j}=1,2, \ldots, \mathrm{p})$, jumlahkan nilai delta masukannya (dari neuron pada lapisan di atasnya)

$\delta_{i n_{j}}=\sum_{k=1}^{m} \delta_{k} w_{j k}$

Kalikan dengan turunan aktivasinya untuk menghitung nilai kesalahannya.

$\delta_{j}=\delta_{i n_{j}} \cdot f^{\prime}\left(z_{i n_{j}}\right)$

Hitung perubahan bobotnya (digunakan nanti untuk merubah nilai $v_{i j}$ )

$$
\Delta v_{i j}=\alpha \cdot \delta_{j} x_{i}
$$

Kemudian hitung perubahan biasnya (digunakan nanti untuk mengubah nilai $v_{0 j}$

update bobot dan bias

9. untuk setiap neuron pada lapisan keluaran ( $\mathrm{Yk}, \mathrm{k}=1,2, \ldots, \mathrm{m})$, ganti nilai bobot dan biasnya $(\mathrm{j}=0,1,2, \ldots, \mathrm{p})$

$$
w_{j k(\text { baru })}=w_{j k \text { (lama) }}+\Delta w_{j k}
$$

untuk setiap neuron pada lapisan tersembunyi $(\mathrm{Zj}, \mathrm{j}=1,2, . ., \mathrm{p})$, ganti nilai bobot dan biasnya $(\mathrm{i}=0,1,2, \ldots, \mathrm{n})$

$$
v_{i j \text { (baru) }}=v_{i j \text { (lama) }}+\Delta v_{i j}
$$

10. Uji/ periksa kondisi berhenti tahapan tersebut diulangi terus-menerus sampai mendapatkan nilai error yang diinginkan (kondisi berhenti).

\subsection{Penyakit Kanker Paru-Paru}

Kanker adalah segolongan penyakit yang ditandai dengan pembelahan sel yang tidak terkendali dan kemampuan sel-sel tersebut untuk menyerang jaringan biologis lainnya, baik dengan pertumbuhan langsung di jaringan yang bersebelahan (invasi) atau dengan migrasi sel ke tempat yang jauh (metastasis). Pertumbuhan yang tidak terkendali tersebut menyebabkan kerusakan DNA. Kanker dapat menyebabkan banyak gejala yang berbeda, bergantung pada lokasinya dan karakter dari keganasan serta adanya metastasis. Diagnosis yang menentukan biasanya membutuhkan pemeriksaan mikroskopik jaringan yang diperoleh dengan biopsi. Setelah didiagnosis, kanker biasanya dirawat dengan operasi, kemoterapi, atau radiasi. Penyebab munculnya kanker berhubungan dengan faktor lingkungan, yang sebenarnya bisa dihindari. Kebiasaan merokok tembakau merupakan penyebab kanker yang utama daripada faktor lingkungan lainnya.

Kanker paru secara sederhana dapat didefinisikan sebagai penyakit ganas di paru, mencakup keganasan yang berasal dari paru sendiri (primer) dan metastasis tumor di paru. Metastasis tumor di paru adalah tumor yang tumbuh sebagai akibat penyebaran (metastasis) dari tumor primer organ lain. Definisi khusus untuk kanker paru primer yakni tumor ganas yang berasal dari epitel bronkus.

\subsubsection{Faktor Risiko}

Orang-orang yang termasuk dalam golongan faktor risiko tinggi atas penyakit paru sebaiknya segera dirujuk ke dokter spesialis paru. Faktor Resiko tinggi untuk penyakit paru dapat 
diketahui melalui faktor-faktor resiko sebagai berikut [4] :

1. Laki-laki,

2. Usia lebih dari 40 tahun

3. Perokok

4. Tinggal/bekerja di lingkungan yang mengandung zat karsinogen atau polusi tinggi

5. Paparan industri / lingkungan kerja tertentu

6. Perempuan perokok pasif

7. Riwayat pernah mendapat kanker organ lain atau anggota keluarga dekat yang menderita kanker paru

\subsubsection{Tanda dan Gejala Utama Kanker Paru}

Keluhan utama kanker paru adalah [4]:

1. Batuk-batuk dengan/tanpa dahak (dahak putih, dapat juga purulen) lebih dari 3 minggu

2. Batuk darah

3. Sesak napas

4. Suara serak

5. Nyeri dada yang persisten

6. Sulit/sakit menelan

7. Benjolan di pangkal leher

8. Sembab muka dan leher, kadang-kadang disertai sembab lengan dengan rasa nyeri yang hebat.

Ada pula gejala dan keluhan tidak khas seperti :

1. Berat badan berkurang

2. Nafsu makan hilang

3. Demam hilang timbul

4. Sindrom paraneoplastik, seperti hypertrophic pulmonary osteoartheopathy, trombosis vena perifer dan neuropatia.

\subsubsection{Diagnosis Kanker Paru}

Pengenalan awal penyakit kanker paru ini sulit dilakukan bila hanya berdasarkan keluhan saja. Biasanya keluhan ringan terjadi pada penderita yang masih dalam stage dini yaitu stage I dan II. Pemeriksaan yang dapat dilakukan untuk pengenalan awal ini, selain pemeriksaan klinis adalah pemeriksaan foto toraks dan pemeriksaan sitologi sputum. Pada foto toraks dapat ditemukan gambaran tumor dengan tepi yang tidak rata dan penarikan pleura dan bahkan destruksi tulang dinding dada. Tidak jarang ditemukan gambaran efusi pleura masif sehingga tumor tidak terlihat. Sitologi sputum akan memberikan hasil positif jika tumor ada dibagian sentral atau intrabronkus.
Prosedur diagnosis untuk kanker paru dilakukan hingga didapat diagnosis pasti (jenis histologis) dan dapat ditentukan stage penyakit hingga dapat diberikan alternatif terapi yang tepat. Prosedur diagnostik untuk mendapatkan sel kanker dapat dilakukan dengan cara paling sederhana hingga tindakan invasif tergantung kondisi pasien. Prosedur diagnosis itu antara lain biopsi jarum halus jika ada massa superfisial, pungsi dan biopsi pleura jika ada efusi pleura, bronkoskopi disertai dengan bilasan, sikatan, kuretase, biopsi massa intrabronkus, sebagai usaha untuk mendapatkan jenis histologis.

Prosedur diagnostik untuk menentukan stage penyakit antara lain, foto toraks, CT-scan toraks sampai kelenjar suprarenal dan bronkoskopi. Pemeriksaan CT-scan kepala dan bone scan dilakukan jika ada keluhan (indikasi) atau pasien yang akan dibedah. Pada kondisi tertentu diagnosis tidak dapat ditegakkan meskipun telah dilakukan berbagai prosedur diagnosis, maka torakotomi eksplorasi dapat dilakukan.

\subsubsection{Jenis Histologis Kanker Paru}

Jenis Sel Kanker Paru secara umum dibagi dua kelompok yaitu :

1. Kanker paru jenis karsinoma sel kecil (KPKSK) atau small cell lung cancer (SCLC).

2. Kanker paru jenis karsinoma bukan sel kecil (KPKBSK) atau non-small cell lung cancer (NSCLC).

\subsubsection{Staging Kanker Paru}

Penderajatan untuk penyakit kanker paru dilakukan berdasarkan standar International Staging System for Lung Cancer berdasarkan TNM. Sistem TNM ini merepresentasikan kanker paru berdasarkan tumor (T), penyebarannya ke getah bening $(\mathrm{N})$ dan organ lain (M). Untuk masing-masing jenis kanker paru berdasarkan histologi memiliki penamaan stage sebagai berikut:

A. Stage kanker paru jenis karsinoma sel kecil (KPKSK) terdiri dari :

1. Stage terbatas (limited) jika hanya melibatkan satu sisi paru (hemitoraks)

2. Stage luas (extensived) jika sudah meluas dari satu hemitoraks atau menyebar ke organ lain.

B. Stage kanker paru jenis karsinoma bukan sel kecil (KPKBSK) dibagi atas : Stage 0, IA, IB, IIA, IIB, IIIA, IIIB dan IV. Kriteria untuk masing-masing stadium ini sekaligus menjadi basis pengetahuan yang 
dipergunakan oleh dokter untuk dapat menentukan stadium kanker paru pada sistem pendukung pengambilan keputusan pendeteksi stadium kanker paru yang dibangun.

\subsection{Arsitektur Sistem Pendukung Keputusan}

Proses pengambilan keputusan melibatkan empat tahap utama yaitu: tahap intelegensi (intelligence phase), tahap perancangan (design phase), tahap pilihan (choise phase), dan tahap implementasi (implementation)[5]. Subsistemsubsistem sistem pendukung keputusan terdiri dari subsistem manajemen data, subsistem manajemen model, susbsistem manajemen pengetahuan, subsistem antar muka pengguna:

a. Subsistem Manajemen Data merupakan subsistem yang menyediakan data bagi sistem. Sumber data berasal dari data internal dan data eksternal.

b. Subsistem Manajemen Model merupakan subsistem yang befungsi sebagai pengelola berbagai model.

c. Subsistem Manajemen Pengetahuan merupakan

Subsistem pendukung subsistem yang lain atau sebagai suatu komponen yang bebas.

d. Subsistem antarmuka pengguna adalah fasilitas yang mampu mengintegrasikan sistem dengan pengguna secara interaktif. Melalui sistem dialog inilah sistem dapat di pahami sehingga pengguna dapat berkomunikasi dengan sistem pendukung keputusan.

Hubungan antar subsistem ini dapat ditunjukkan pada Gambar 2.

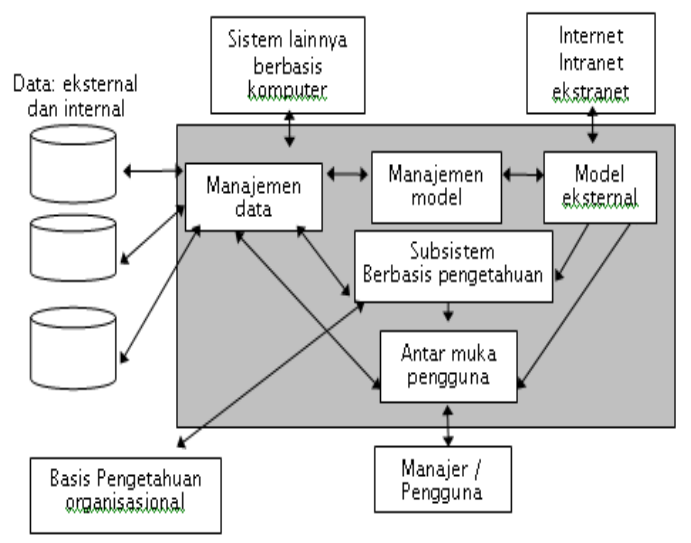

Gambar 2 Skema sistem pendukung keputusan

Berdasarkan skema diatas maka akan dibangun sistem pendukung keputusan klinis yang melibatkan dua aplikasi utama yang masing-masing memiliki peranan yang berbeda, untuk aplikasi pendukung pengambilan keputusan dibuat dengan bahasa pemograman Visual Basic 6 yang ditambahkan modul aplikasi dicom viewer untuk membantu dalam diagnosa penyakit berupa image dicom, untuk aplikasi JST menggunakan Encog-NN yang dibangun menggunakan bahasa pemograman java.

\subsection{Kriteria Penilaian Pengambilan Keputusan}

Semua informasi dalam mendiagnosa penyakit paru ini akan di kumpulkan dan diklasifikasikan dalam bentuk data eksternal dan internal sehingga dapat dipakai untuk membuat penilaian pada sistem pendukung keputusan.

Sumber data dalam sistem pendukug pengambilan keputusan dapat dikategorikan pada data eksternal dan data internal, dimana pada sistem pendukung keputusan klinis pendeteksi kanker paru juga memanfaatkan kedua sumber data ini.

Data eksternal merupakan data yang tidak berhubungan langsung dengan klinis penyakit kanker paru secara langsung tetapi mempengaruhi dalam sistem pendukung keputusan. Adapun data yang termasuk dalam data eksternal adalah sebagai berikut: data identitas pasien (kartu tanda penduduk), data demografi dan lingkungan tempat tinggal.

Data internal merupakan data yang berhubungan langsung dengan klinis penyakit paru untuk mendukung sistem pendukung keputusan. Adapun yang tergolong dalam data internal: data rekam medis sebelumnya, data gejala penyakit, data hasil pemeriksaan laboratorium

Data internal dan eksternal dapat di ekstrak dari berbagai data yang dibutuhkan untuk merancang sistem pendukung keputusan klinis untuk menentukan stadium penyakit kanker paru. Data-data yang telah di ekstrak tersebut diberi parameter/kriteria penilaian kemudian dimasukkan dalam jaringan syaraf tiruan dengan metode multilayer perceptron dan backpropagation kemudian diperoleh output yang dipakai sebagai komponen penentu nilai stadium penderita penyakit kanker paru pada sistem pendukung keputusan klinis yang dirancang.

Diagnosa penyakit paru berdasarkan anamnesis perlu mengetahui keluhan utama pasien, mencari apakah sumber keluhan pada metastesis penyakit yang diderita, terkadang pasien merasa tidak memiliki keluhan yang khas. Pemeriksaan fisik jasmani dapat dilakukan untuk membantu dalam diagnosa, apakah terjadi kelumpuhan organ, sindrom, benjolan, suara, 
yang terjadi pada sekitar paru. Pemeriksaan lebih dalam adalah menggunakan pemeriksaan radiologis menggunakan computed temography imaging yang sering di sebut CT-Scan untuk mencari metastesis pada dada, otak, atau tulang.

Data internal dan eksternal yang diekstrak dibagi dalam empat penilaian sistem pendukung keputusan klinis yaitu: penilaian identitas pasien, penilaian gejala penyakit (umum dan khusus), penilaian lingkungan dan kebiasaan pasien, penilaian pemeriksaan dokter. Dimana masingmasing penilaian tersebut memiliki beberapa elemen penilaian yang akan menentukan nilai akhir sistem pendukung keputusan klinis, bentuk penilaian masing-masing kriteria adalah sebagai berikut:

\subsubsection{Penilaian kriteria pasien.}

Dalam penilaian ini yang menjadi tolak ukur adalah dari segi umur dan jenis kelamin pasien, keduanya berpengaruh langsung pada tingkat stadium penyakit. Untuk penilaian pasien dengan umur yang lebih tua memiliki tingkat rentan lebih tinggi dibandingkan dengan umur pasien yang relative lebih muda. Berdasarkan jenis kelamin pasien, dimana kasus laki-laki lebih sering terjangkit kanker paru lebih besar dari pada pasien berjenis kelamin wanita. Umur dan jenis kelamin pasien dijadikan bagian dari inputan jaringan syaraf buatan yang akan menentukan nilai stadium penyakit kanker paru, bentuk penilaian secara spesifik dapat disajikan pada Tabel 1

Tabel 1 Penilaian kriteria identitas pasien

\begin{tabular}{|c|c|c|c|}
\hline $\begin{array}{l}\text { Identitas } \\
\text { Pasien }\end{array}$ & Skala/Ket & Penilaian & Node \\
\hline Umur/usia & $<20$ thn & 0 & \multirow{5}{*}{ G1 } \\
\hline & $20-35$ thn & 0.25 & \\
\hline & $36-50$ thn & 0.5 & \\
\hline & $51-65$ thn & 0.75 & \\
\hline & $>65$ th & 1 & \\
\hline Jenis Kelamin & Pria & 1 & \multirow{2}{*}{ G2 } \\
\hline & Wanita & 0.5 & \\
\hline
\end{tabular}

\subsubsection{Penilaian kriteria gejala penyakit.}

Dalam penilaian kriteria gejala penyakit yang menjadi perhatian utama dalam menentukan stadium penyakit kanker paru adalah gejala utama dari penyakit kanker paru, penilaian secara spesifik dapat disajikan pada Tabel 2.

Tabel 2 Penilaian kriteria gejala penyakit

\begin{tabular}{|l|l|l|l|}
\hline $\begin{array}{l}\text { Gejala } \\
\text { Penyakit }\end{array}$ & Skala/Ket & Nilai & $\begin{array}{l}\text { No } \\
\text { de }\end{array}$ \\
\hline Batuk Darah & Tidak Batuk & 0 & \\
\hline & Ringan $(<25 \mathrm{ml} / 24 \mathrm{jam})$ & 0.25 & \multirow{2}{*}{ G3 } \\
\cline { 1 - 2 } & $\begin{array}{l}\text { Sedang }(25-250 \mathrm{ml} / 24 \\
\text { jam) }\end{array}$ & 0.5 & \\
\hline & $\begin{array}{l}\text { Berat }(250- \\
\text { 600ml/24jam })\end{array}$ & 0.75 & \\
\hline
\end{tabular}

\begin{tabular}{|c|c|c|c|}
\hline & Masif $(>600 \mathrm{ml} / 24 \mathrm{jam})$ & 1 & \\
\hline \multirow[t]{2}{*}{ Demam } & Demam & 1 & \multirow{2}{*}{ G4 } \\
\hline & Tidak demam & 0 & \\
\hline \multirow[t]{2}{*}{ Sesak Napas } & Ya & 1 & \multirow{2}{*}{ G5 } \\
\hline & Tidak & 0 & \\
\hline \multirow[t]{2}{*}{$\begin{array}{l}\text { Sakit dada } \\
\text { persisten }\end{array}$} & Ya & 1 & \multirow{2}{*}{ G6 } \\
\hline & Tidak & 0 & \\
\hline \multirow[t]{2}{*}{$\begin{array}{l}\text { Benjolan di } \\
\text { pangkal leher }\end{array}$} & Ya & 1 & \multirow[t]{2}{*}{ G7 } \\
\hline & Tidak & 0 & \\
\hline \multirow[t]{2}{*}{ Suara serak } & Ya & 1 & \multirow{2}{*}{ G8 } \\
\hline & Tidak & 0 & \\
\hline \multirow[t]{2}{*}{$\begin{array}{l}\text { Sembab muka } \\
\text { dan leher }\end{array}$} & Ya & 1 & \multirow{2}{*}{ G9 } \\
\hline & Tidak & 0 & \\
\hline \multirow[t]{2}{*}{$\begin{array}{l}\text { Pembesaran } \\
\text { KGB } \\
\end{array}$} & Ya & 1 & \multirow{2}{*}{ G10 } \\
\hline & Tidak & 0 & \\
\hline
\end{tabular}

\subsubsection{Penilaian kriteria lingkungan dan} kebiasaan pasien.

Penilaian kriteria lingkungan dan kebiasaan pasien diperoleh dari faktor resiko tinggi dengan penilaian secara spesifik disajikan pada Tabel 3

Tabel 3 Penilaian kriteria lingkungan dan kebiasaan pasien

\begin{tabular}{|c|c|c|c|}
\hline $\begin{array}{l}\text { Lingkungan dan } \\
\text { Kebiasaan }\end{array}$ & Skala & nilai & Node \\
\hline \multirow[t]{2}{*}{ Perokok } & Tidak merokok & 0 & \multirow[b]{2}{*}{ G11 } \\
\hline & $\begin{array}{l}\text { Pasien adalah } \\
\text { perokok aktif atau } \\
\text { pasif }\end{array}$ & 1 & \\
\hline \multirow[t]{2}{*}{$\begin{array}{l}\text { Lokasi T T dekat Pabrik, } \\
\text { atau daerah polusi tinggi }\end{array}$} & Ya & 1 & \multirow[t]{2}{*}{ G12 } \\
\hline & Tidak & 0 & \\
\hline \multirow[t]{2}{*}{$\begin{array}{l}\text { Riwayat anggota keluarga } \\
\text { penderita penyakit paru }\end{array}$} & Tidak ada & 0 & \multirow{2}{*}{ G13 } \\
\hline & Ada & 1 & \\
\hline
\end{tabular}

\subsubsection{Penilaian kriteria diagnosa/pemeriksaan dokter.}

Penilaian kriteria diagnosa/pemeriksaan dokter dalam hal ini berhubungan dengan pemeriksaan spesifik menggunakan ct-scan yang dilakukan oleh dokter spesialis paru dimana dokter menganalisa dan menentukan sendiri penilaian fisik paru dengan penilaian standar TNM. Penilaian sekaligus menentukan seberapa besar ukuran tumor, jumlah, sebaran dan posisi dari kanker, bentuk penilaian secara spesifik dapat disajikan pada Tabel 4.

Tabel 4 Penilaian kriteria diagnosa

\begin{tabular}{|c|c|c|c|}
\hline Diagnosa dan pemeriksaan & Skala/Ket & nilai & $\begin{array}{l}\text { No } \\
\text { de }\end{array}$ \\
\hline Tidak ditemukan tumor & Tx N0 M0 & 0.13 & \\
\hline & T1 N0 M0 & 0.25 & G14 \\
\hline
\end{tabular}




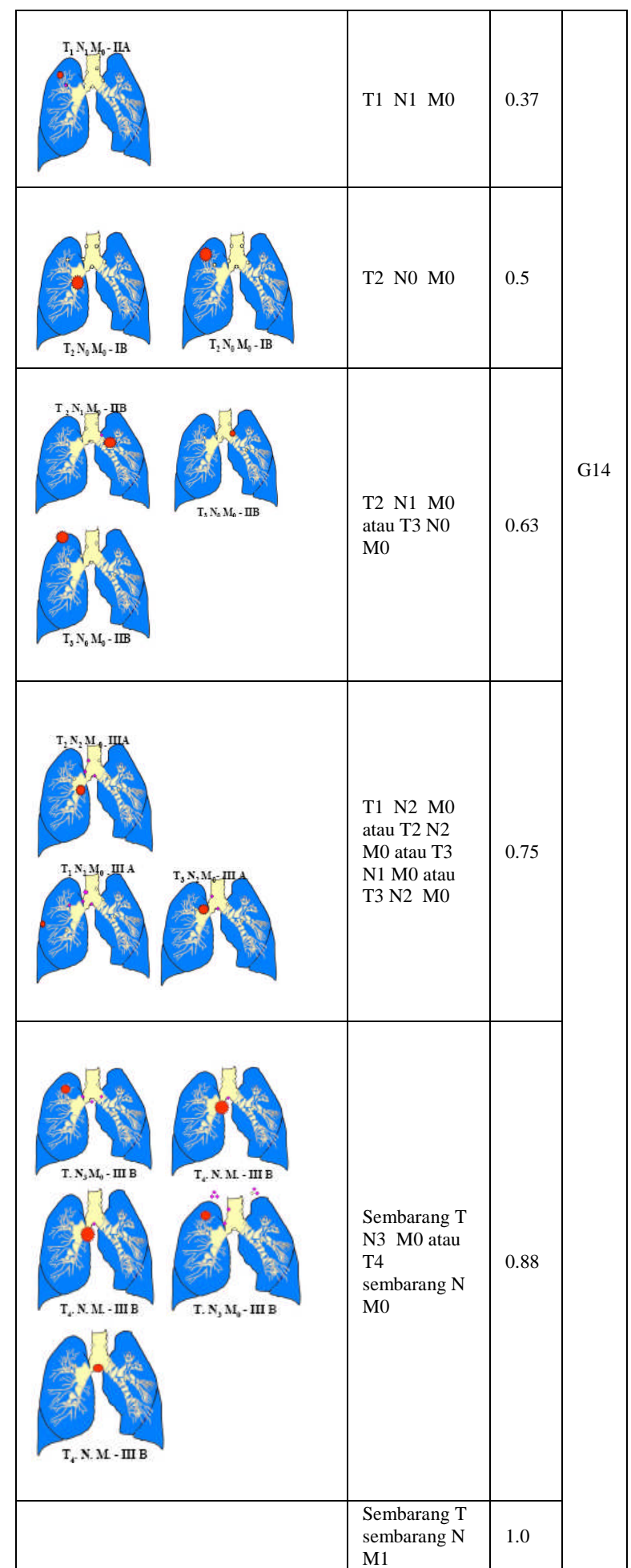

Untuk setiap penilaian kriteria akan di berikan bobot sesuai dengan keinginan pembuat keputusan, misalkan untuk kriteria penilaian identitas pasien karena tidak terlalu signifikan mempengaruhi diagnosa maka diberikan bobot $10 \%$, penilaian gejala penyakit diberikan bobot $20 \%$, penilaian lingkungan dan kebiasaan pasien $30 \%$ dan penilaian pemeriksaan dokter diberikan bobot lebih tinggi karena dianggap sangat mempengaruhi diagnosa secara signifikan maka diberikan bobot $40 \%$, bentuk represenasi bobot sistem ini disajikan pada Tabel 5.

Tabel 5 Bobot Penilaian kriteria

\begin{tabular}{|l|c|}
\hline Kriteria & $\begin{array}{l}\text { BobotPenilaian } \\
\text { Kriteria }\end{array}$ \\
\hline penilaian identitas pasien & $10 \%$ \\
\hline penilaian gejala penyakit & $20 \%$ \\
\hline $\begin{array}{l}\text { penilaian lingkungan dan kebiasaan } \\
\text { pasien }\end{array}$ & $30 \%$ \\
\hline penilaian pemeriksaan dokter & $40 \%$ \\
\hline
\end{tabular}

Setelah melakukan identifikasi input maka di dapatkan 14 input yang direpresentasikan dalam node G1 sampai G14, semua input ini akan dilatih agar dapat mengenali pola yang telah di tentukan melalui jaringan syaraf tiruan Multilayer Perceptron Backpropagatian, dan output terbaik yang mendekati target akan diambil sebagai elemen penentu stadium kanker paru yang akan di hasilkan dalam sistem pendukung keputusan klinis yang dibuat.

\subsection{Model Pengambilan Keputusan}

Pengambilan keputusan berdasarkan pola jaringan saraf tiruan yang terdiri dari lapisan masukan 14 unit sel saraf dan lapisan keluaran/output terdiri atas 3 sel saraf. Lapisan masukan digunakan untuk menampung 14 variabel yaitu G1 sampai dengan G14, dan 3 lapisan keluaran digunakan untuk mempresentasikan target output dengan pengelompokan pola nilai 000 untuk stadium 0 , nilai 001 untuk stadium IA, nilai 010 untuk stadium IB, nilai 100 untuk stadium IIA, nilai 011 untuk stadium IIB, nilai 101 untuk stadium IIIA, nilai 110 untuk stadium IIIB dan nilai 111 untuk stadium IV.

Bentuk arsitektur jaringan yang di gunakan pada sistem pendukung keputusan klinis dapat ditunjukkan pada Gambar 3, bentuk arsitektur ini dipilih berdasarkan kecepatan dalam mengenali pola target sehingga disegi waktu juga lebih efisien, hal ini akan dibahas pada bab selanjutnya.

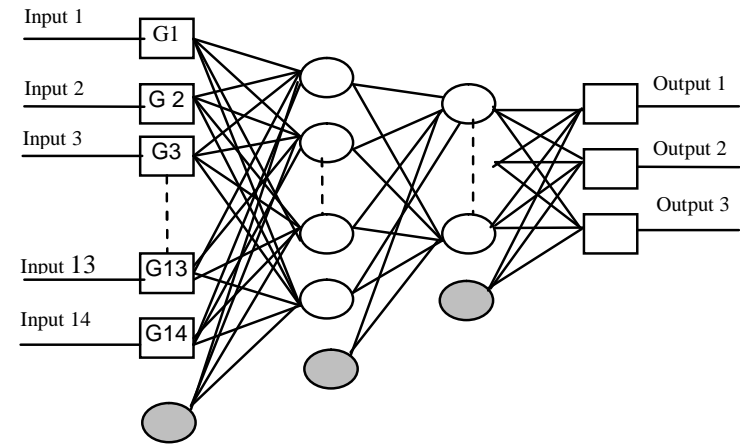

Gambar 3 Arsitektur jaringan syaraf tiruan SPKK 
Setelah memperoleh hasil pelatihan yang mendekati pola yang telah ditentukan, nilai tersebut di jadikan komponen bobot penilaian pada sistem pendukung pengambilan keputusan klinis yang dirancang agar dapat menghasilkan nilai tertentu yang menunjukkan nilai stadium diagnosa sistem.

Secara matematis nilai stadium diagnosa sistem $(y)$ di peroleh dari penjumlahan semua elemen penilaian yang merupakan inputan sistem yang sudah dikalikan dengan masing-masing nilai bobot kriteria $(f)$ kemudian dikalikan dengan total bobot $(t w)$, sebagaimana ditunjukkan pada persamaan (12):

$y=\left(\left(\sum G_{(1-2)} \times f_{1}\right)+\left(\sum G_{(3-10)} \times f_{2}\right)+\left(\sum G_{(1-13)} \times f_{3}\right)+\left(G_{(14)} \times f_{4}\right)\right) \times t w(12)$

Total bobot (tw) yang digunakan sesuai dengan tingkat TNM yang diperoleh dari permeriksaan dokter.

\section{HASIL DAN PEMBAHASAN}

Implemenasi jaringan syaraf multilayer perceptron dengan menggunakan metode pembelajaran backpropagation dilatih menggunakan aplikasi Encog Workbenck, Aplikasi Encog merupakan salah satu aplikasi open source yang dapat digunakan untuk melakukan pemodelan jaringan syaraf tiruan dengan berbagai metode.

Data training set yang digunakan merupakan data klinikal yang dilatih agar dapat mengenali pola-pola yang merepresentasikan nilai output, dengan menggunakan berbagai kombinasi layer dan jumlah neuron dalam arsitektur multilayer perceptron (feedforward neural network), data training di latih agar memperolah hasil error/galat yang minimum, hasil kombinasi layer dengan iterasinya yang dilakukan ditunjukkan pada Tabel 6.

Tabel 6 Perbandingan jumlah iterasi dan error berbagai kombinasi neuron pada hidden layer

\begin{tabular}{|c|c|c|c|c|c|}
\hline $\begin{array}{c}\text { Learning } \\
\text { Rate }\end{array}$ & $\begin{array}{c}\text { Hidden } \\
\text { Layer } \\
1\end{array}$ & $\begin{array}{c}\text { Hidden } \\
\text { Layer } \\
2\end{array}$ & $\begin{array}{c}\text { Current } \\
\text { Error }\end{array}$ & $\begin{array}{c}\text { Improv } \\
\text { Error }\end{array}$ & $\begin{array}{c}\text { Iterasi } \\
\text { (epoch) }\end{array}$ \\
\hline 0.1 & 0 & 0 & 0.999992 & 0.00298 & 17.113 \\
\hline 0.1 & 3 & 3 & 0.999960 & 0.00480 & 12.582 \\
\hline 0.1 & 3 & 4 & 0.999977 & 0.00571 & 9.694 \\
\hline 0.1 & 4 & 3 & 0.999997 & 0.00294 & 18.068 \\
\hline 0.1 & 4 & 4 & 0.999982 & 0.00464 & 11.623 \\
\hline 0.1 & 4 & 5 & 0.999934 & 0.00790 & 6.909 \\
\hline 0.1 & 4 & 6 & 0.999953 & 0.00765 & 7.515 \\
\hline 0.1 & 4 & 7 & 0.999953 & 0.00937 & 6.225 \\
\hline 0.1 & 5 & 3 & 0.999973 & 0.00288 & 18.452 \\
\hline 0.1 & 5 & 4 & 0.999999 & 0.00616 & 10.002 \\
\hline 0.1 & 5 & 5 & 0.999953 & 0.00857 & 6.504 \\
\hline 0.1 & 5 & 6 & 0.999921 & 0.01165 & 4.965 \\
\hline 0.1 & 5 & 7 & 0.999956 & 0.00985 & 5.630 \\
\hline 0.1 & 6 & 3 & 0.999939 & 0.00617 & 8.917 \\
\hline 0.1 & 6 & 4 & 0.999318 & 0.09788 & 87.409 \\
\hline 0.1 & 6 & 5 & 0.999931 & 0.00765 & 7.063 \\
\hline 0.1 & 6 & 6 & 0.999975 & 0.01118 & 5.517 \\
\hline 0.1 & 7 & 7 & 0.999939 & 0.01144 & 4.693 \\
\hline
\end{tabular}

Jumlah iterasi pada jaringan yang di pilih adalah 4.693 dengan tingkat error 0.999939 , hal ini bukan tingkat error minimal yang dihasilkan karena masih ada model yang menghasilkan pola dengan tingkat error lebih kecil, tetapi disisi kecepatan lebih unggul. Parameter-parameter jaringan syaraf tiruan yang digunakan antara lain: 14 input, 3 output, fungsi aktivasi sigmoid, learning rate $0.1,7$ neuron pada hidden layer pertama, 7 neuron pada hidden layer ke dua, 3 neuron bias masing-masing pada layer input dan hidden layer, maximum error di set dengan nilai 0.01 , momentum disetting dengan nilai 0.0 , semua nilai setting ini dapat di ubah agar dapat mempengaruhi hasil output yang lebih tepat untuk mengenali pola output. Pelatihan data pada model arsitektur JST menggunakan perangkat keras dengan spesifikasi prosessor intel core 2 duo dengan memori $1 \mathrm{~Gb}$.

Jenis pelatihan data pada jaringan syaraf tiruan yang dipakai merupakan pelatihan yang terawasi (supervised learning), oleh karena itu jaringan ini memiliki target output yang di tentukan. Untuk melakukan pelatihan terhadap jaringan syaraf (neural-network), terlebih dahulu kita inputkan data training dan target, dalam penelitian ini data yang di input merepresentasikan gejala dan diagnosa kanker paru, sedangkan nilai output yang dihasilkan merepresentasikan tingkat stadium kanker paru yang di derita oleh pasien.

Setelah melakukan pelatihan data dengan model jaringan yang telah ditentukan, maka akan dihasilkan output data yang merupakan pola terbaik dalam mendekati nilai ideal yang di inginkan. Dari setiap data yang di latih akan menghasilkan nilai output yang berbeda sehingga dapat di jadikan pola data pada data test yang lainnya, harapannya agar nilai output yang dihasilkan pada saat pelatihan sama dengan nilai output yang di hasilkan pada saat menggunakan data test sesungguhnya.

Pada penelitian ini, nilai output hasil pelatihan yang dihasilkan model jaringan syaraf yang di pilih di tunjukkan pada Tabel 7.

Tabel 7 Pola output pelatihan data pada jaringan syaraf tiruan

\begin{tabular}{|l|l|l|l|r|l|}
\hline No. & Output 1 & Output 2 & \multicolumn{1}{|c|}{ Output 3 } & Total Output & Stadium \\
\hline 1 & 0.009948 & 0.011197 & 0.008415 & 0.029560 & Stadium 0 \\
\hline 2 & 0.991291 & 0.009995 & 0.008897 & 1.010182 & Stadium IIA \\
\hline 3 & 0.009609 & 0.009735 & 0.991808 & 1.011152 & Stadium IA \\
\hline 4 & 0.008653 & 0.990995 & 0.992167 & 1.991815 & Stadium IIB \\
\hline 5 & 0.991291 & 0.009995 & 0.008897 & 1.010182 & Stadium IIA \\
\hline 6 & 0.011749 & 0.010491 & 0.993967 & 1.016207 & Stadium IA \\
\hline 7 & 0.989127 & 0.990218 & 0.009284 & 1.988628 & Stadium IIIB \\
\hline 8 & 0.990037 & 0.985518 & 0.990099 & 2.965654 & Stadium IV \\
\hline 9 & 0.005529 & 0.988847 & 0.990307 & 1.984683 & Stadium IIB \\
\hline 10 & 0.990041 & 0.990208 & 0.010273 & 1.990522 & Stadium IIIB \\
\hline 11 & 0.010542 & 0.010076 & 0.993001 & 1.013619 & Stadium IA \\
\hline 12 & 0.993119 & 0.014392 & 0.995243 & 2.002755 & Stadium IIIA \\
\hline 13 & 0.009948 & 0.011197 & 0.008415 & 0.029560 & Stadium 0 \\
\hline
\end{tabular}




\begin{tabular}{|l|r|r|r|r|l|}
\hline 14 & 0.989556 & 0.00852 & 0.008061 & 1.006137 & Stadium IIA \\
\hline 15 & 0.010843 & 0.011708 & 0.00895 & 0.031501 & Stadium 0 \\
\hline 16 & 0.990041 & 0.990208 & 0.010273 & 1.990522 & Stadium IIIB \\
\hline 17 & 0.989556 & 0.00852 & 0.008061 & 1.006137 & Stadium IIA \\
\hline 18 & 0.013048 & 0.982833 & 0.008306 & 1.004187 & Stadium IB \\
\hline 19 & 0.992867 & 0.012234 & 0.994468 & 1.999569 & Stadium IIIA \\
\hline 20 & 0.990302 & 0.98638 & 0.990213 & 2.966896 & Stadium IV \\
\hline 21 & 0.989127 & 0.990218 & 0.009284 & 1.988628 & Stadium IIIB \\
\hline 22 & 0.992616 & 0.011542 & 0.994104 & 1.998262 & Stadium IIIA \\
\hline 23 & 0.990302 & 0.98638 & 0.990213 & 2.966896 & Stadium IV \\
\hline 24 & 0.005529 & 0.988847 & 0.990307 & 1.984683 & Stadium IIB \\
\hline 25 & 0.991291 & 0.009995 & 0.008897 & 1.010182 & Stadium IIA \\
\hline 26 & 0.014422 & 0.985313 & 0.010976 & 1.010711 & Stadium IB \\
\hline 27 & 0.990037 & 0.985518 & 0.990099 & 2.965654 & Stadium IV \\
\hline 28 & 0.009609 & 0.009735 & 0.991808 & 1.011152 & Stadium IA \\
\hline 29 & 0.993031 & 0.013164 & 0.994852 & 2.001047 & Stadium IIIA \\
\hline 30 & 0.006829 & 0.990053 & 0.991329 & 1.988211 & Stadium IIB \\
\hline
\end{tabular}

Dari output pola yang dihasilkan dapat di ketahui bahwa pola output yang dihasilkan pelatihan dapat mendekati pola target, sesuai dengan yang diharapkan, dari pola juga dapat di lihat bahwa semakin tinggi nilai total output maka semakin tinggi tingkat stadiumnya.

\subsection{Implementasi Sistem Pendukung Keputusan Klinis}

\subsubsection{Dialog Menu Utama}

Form menu utama ini dapat ditampilkan apabila user telah melaksanakan login sistem secara benar. Pada dialog bagian menu utama ini terdapat beberapa menu yaitu: menu File yang mencakup fungsi-fungsi utama pada SPKK, menu Tools yang mencakup fungsi pengaturan sistem dan diagnosa data berupa citra yang diberikan untuk pelengkap SPKK, menu Services dimana mencakup menu pencarian data serta cetak hasil diagnosa, dan yang terakhir menu Help yang mencakup informasi cara penggunaan SPKK, secara nyata bentuk form Menu Utama ini ditunjukkan oleh Gambar 4.

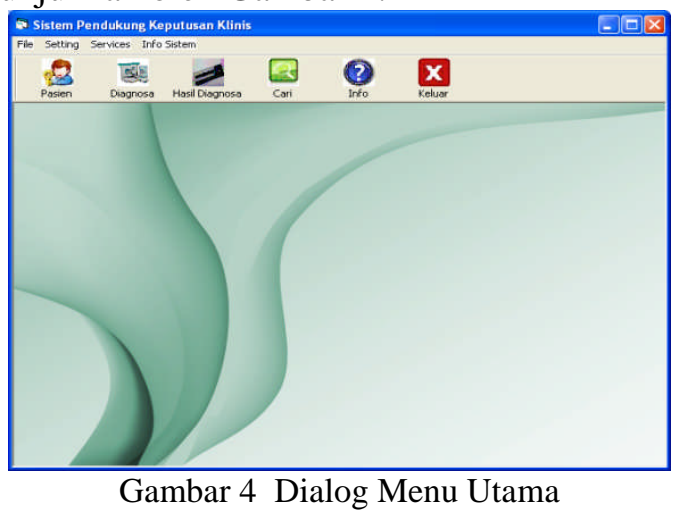

Form menu utama ini merupakan wadah semua aktivitas sistem yang bekerja, form ini menjadi sarana untuk mengakses semua fitur yang ada pada sistem.

\subsubsection{Dialog Menu Form Diagnosa}

Form diagnosa ini akan memuat informasiinformasi yang digunakan untuk mendiagnosa pasien, form ini menyediakan kebutuhan informasi yang terdiri dari informasi data pasien, data gejala penyakit, dan data pemeriksaan pasien, bentuk form diagnosa ditunjukkan Gambar 5.

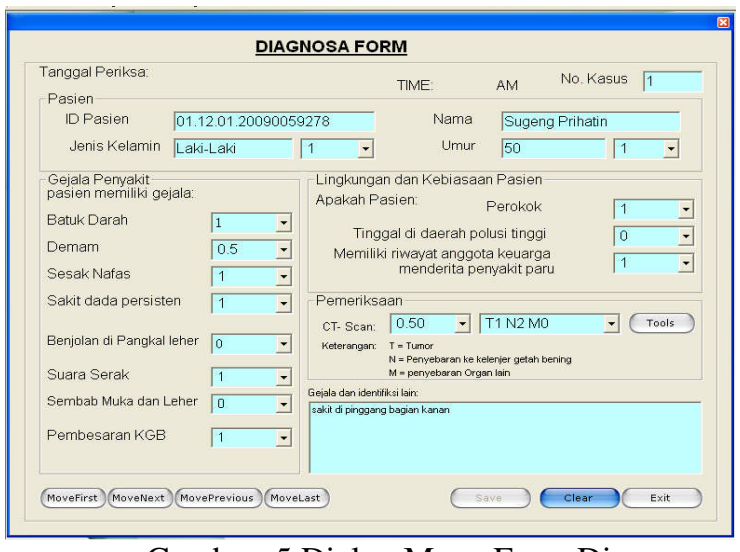

Gambar 5 Dialog Menu Form Diagnosa

Dokter memberikan penilaian untuk masingmasing faktor yang mempengaruhi tingkat stadium penyakit yang di derita oleh pasien, melalui combo box yang di sediakan dengan rentang nilai untuk setiap gejala sudah di tentukan nilainya, dokter dapat memilih sesuai dengan keadaan fisik pasien sesungguhnya.

\subsubsection{Dialog Fasilitas Tool Diagnosa}

Pada form diagnosa ini juga disediakan tool (dicom viewer) berupa aplikasi pemeriksaan hasil ct-scan dengan format image yang dapat dimanfaatkan oleh dokter untuk mendiagnosa penyebaran, ukuran dan banyaknya kanker dalam paru-paru pasien. Tool dicom viewer ini dapat diakses melalui dialog sub menu form diagnosa atau melalui menu services. Bentuk tool ini dapat ditunjukkan pada Gambar 6 .

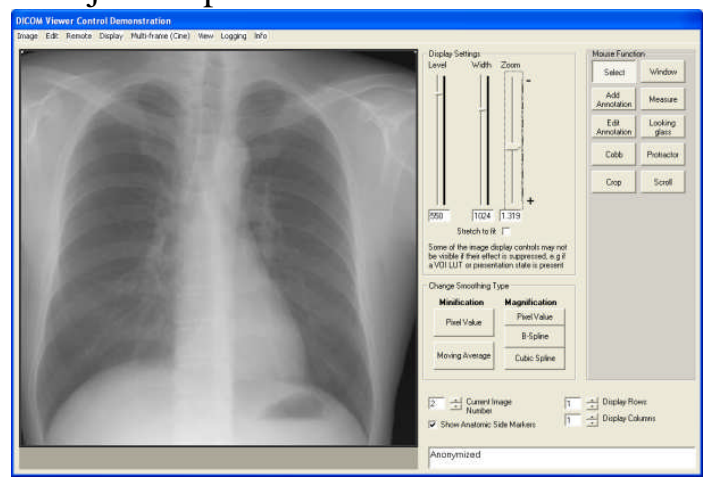

Gambar 6 Dialog Fasilitas Tool Diagnosa (Dicom Viewer)

Dicom viewer ini merupakan modul aplikasi dengan fitur yang dapat membantu dokter menganalisa medical image berformat dicom (Digital Imaging and Communications in Medicine). Platform aplikasinya yang menggunakan Visual Basic 6 membuat modul ini dapat di integrasikan kedalam aplikasi sistem 
pendukung keputusan klinis yang dibuat. Model aplikasi sejenis berbasis java seperti: MIPAV, Microdicom, eViewBox, dan imageJ. Aplikasi sejenis yang sifatnya licenses seperti: OsirixDicom, Hipax, SanteDicomViewer, dan Rubo Dicom Vierwer.

\subsubsection{Setting Bobot Dalam Sistem SPKK}

Output hasil pelatihan data pada JST dipilih sesuai dengan tingkat stadium masing-masing yang memiliki tingkat error paling minimum, kemudian dari ketiga output masing-masing dijumlahkan sehingga diperoleh total output.

Total output ini di inputkan pada sistem pendukung keputusan klinis melalui Setting Bobot, sebagaimana yang disajikan pada Gambar 7, untuk dapat menghasilkan nilai yang proposional dengan faktor penentu stadium penyakit kanker, dokter atau user pengguna sistem dapat mengedit atau mengubah faktor penilaian untuk ke empat masing-masing penilaian kriteria. Pada penelitian ini faktor data pasien mempengaruhi 10\% tingkat stadium penyakit, gejala penyakit mempengaruhi $20 \%$ tingkat stadium penyakit, faktor lingkungan dan kebiasaan pasien mempengaruhi 30\% tingkat stadium penyakit dan data hasil pemeriksaan dokter $40 \%$ mempengaruhi tingkat stadium penyakit.

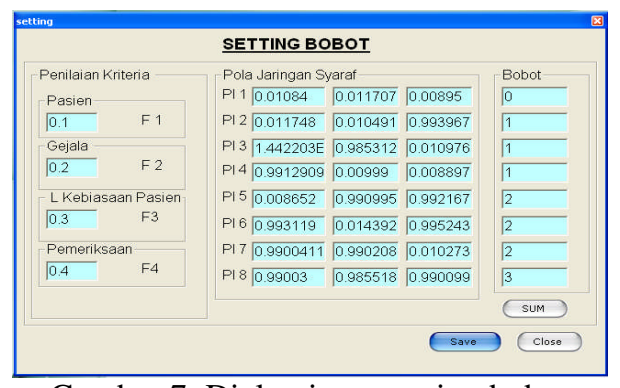

Gambar 7 Dialog input setting bobot

Mekanisme perhitungan dalam sistem SPKK melibatkan empat faktor penilaian, 14 input jaringan dan pola jaringan yang telah disimpan pada sistem. Setelah dokter menginputkan data penilaian untuk masingmasing faktor, secara otomatis sistem akan menjumlahkan nilai yang diberikan untuk setiap kriteria masing-masing faktor kemudian dikalikan dengan nilai bobot kriteria penilaian masing-masing, pola jaringan akan menghitung total bobot sehingga total penjumlahan penilaian yang telah di kalikan dengan nilai bobot kriteria dikalikan dengan total bobot pola jaringan sehingga menghasilkan nilai stadium diagnosa sistem.

\subsubsection{Identifikasi Stadium Penyakit}

Langkah yang dilakukan user untuk melakukan identifikasi stadium penyakit yaitu dengan menekan tombol proses agar dapat melakukan perhitungan terhadap data diagnosa yang sudah di inputkan terlebih dahulu pada form diagnosa. Nilai perhitungan diagnosa sistem akan muncul setelah prograss bar selesai, sistem juga akan menanpilkan nilai stadium kanker paru berdasarkan hasil diagnosa sistem. Hasil diagnosa sistem ini bukan satu-satunya penilaian mutlak penentuan stadium penyakit kanker pasien, sistem hanya membantu mendiagnosa dan hasilnya menjadi referensi bagi dokter paru, untuk menegakkan diagnosa sesungguhnya. Bentuk hasil identifikasi stadium penyakit kanker paru disajikan pada Gambar 8 .

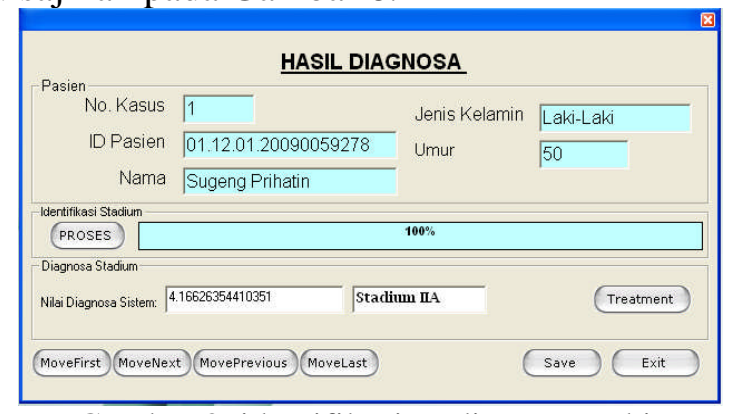

Gambar 8 identifikasi stadium penyakit

\section{KESIMPULAN}

Sistem pendukung keputusan klinis pendeteksi stadium kanker paru termasuk aplikasi dengan skala kecil, secara arsitektur merupakan stand alone aplikasi yang digunakan oleh dokter paru. Ditinjau dari sudut pandang aktivitas penggunaan sistem, aplikasi ini termasuk jenis active user approach [6].

Dari aplikasi sistem pendukung keputusan klinis pendeteksi stadium penyakit kanker paru yang sudah di bangun, di ambil beberapa kesimpulan:

1. Aplikasi sistem pendukung keputusan pendeteksi stadium kanker paru memanfaatkan pola backpropagation untuk desain nilai diagnosa stadium kanker paru.

2. Aplikasi yang di bangun dapat di gunakan sebagai pendukung proses administrasi dan dokumentasi medis di samping fungsi utamanya sebagai pendukung keputusan klinis pendeteksi stadium kanker paru.

3 Sistem hanya membantu mendiagnosa dan hasil penilaian sistem menjadi referensi bagi dokter paru. 
4 Aplikasi yang di buat masih sederhana dengan fitur aplikasi yang diharapkan dapat menunjang keputusan klinis.

\section{SARAN}

Perangkat lunak sistem aplikasi yang dibuat, masih terdapat banyak kekurangan dan kelemahan sehingga perlu di sempurnakan, penggunaan pola jaringan syaraf yang dilatih masih belum terintegrasi dalam sistem yang di buat, oleh karena itu ada beberapa saran untuk penelitian selanjutnya:

1. perlu mengintegrasikan aplikasi jaringan syaraf kedalam sistem untuk memudahkan pencarian pola yang lebih baik.

2. disarankan untuk mencoba model pelatihan jaringan syaraf yang lain untuk mendeteksi stadium kanker paru dalam sistem ini.

3. disarankan untuk mencari perbandingan hasil yang lebih optimal dengan bentuk arsitektur yang lebih komplek.

\section{DAFTAR PUSTAKA}

[1] Mendonca, E. A., 2004, Clinical Decision Support Systems: Perspective in Dentistry. Journal of Dental Education, Pp 589-597.

[2] Siang, J.J., 2005, Jaringan Syaraf Tiruan dan Pemrogramannya Menggunakan Matlab, Andi, Yogyakarta.

[3] Fausett, L., 1994, Fundamentals of Neural Networks: Architectures, Algorithms, and Applications, Prentice-Hall, New Jersey.

[4] Anonim, 2003, Kanker Paru: pedoman diagnosis dan penatalaksanaan di Indonesia, Perhimpunan Dokter Paru Indonesia.

[5] Turban, E., Aronson, J.E., 2001, Decision Support Systems and Intelligent Systems. International Edition, Ed.6, New Jersey.

[6] Kurniawan. R., 2011, Sistem Pendukung Keputusan Klinis Menggunakan Jaringan Syaraf Tiruan Backpropagation Untuk Mendeteksi Stadium Penderita Kanker Paru-Paru Jenis Karsinoma Bukan Sel Kecil, Tesis, Program Pasca Sarjana Ilmu Komputer, Univ. Gadjah Mada, Yogyakarta. 